\title{
MIGRASI VERTIKAL ZOOPLANKTON DI LAUT BANDA
}

\author{
VERTICAL MIGRATION OF ZOOPLANKTON AT THE BANDA SEA
}

\section{Domey Moniharapon ${ }^{1,2}$, Indra Jaya ${ }^{1}$, Henry Manik ${ }^{1}$, Sri Pujiyati ${ }^{1}$, Totok Hestirianoto ${ }^{1}$ dan Augy Syahailatua ${ }^{3}$}

\author{
${ }^{1}$ Departemen Ilmu dan Teknologi Kelautan, Fakultas Perikanan dan Ilmu Kelautan, Institut Pertanian Bogor \\ ${ }^{2}$ Program Studi Ilmu Kelautan, Fakultas Perikanan dan Ilmu kelautan, Universitas Pattimura, Ambon \\ ${ }^{3}$ Balai Konservasi Biota Laut Ambon, Lembaga Ilmu Pengetahuan Indonesia, Ambon \\ E-mail: witten2010@yahoo.com
}

Diterima tanggal: 20 April 2014, diterima setelah perbaikan: 18 Nopember 2014, disetujui tanggal: 28 Nopember 2014

\begin{abstract}
ABSTRAK
Analisis migrasi vertikal zooplankton di Laut Banda telah dilakukan berdasarkan nilai hambur balik akustik yang diperoleh dari pengukuran pada tanggal 21-30 November 2013 menggunakan instrument akustik simrad EK 500 yang dipasang pada Kapal Riset Baruna Jaya VII. Hasil analisis menunjukan migrasi vertikal zooplankton di Laut Banda merupakan fungsi dari waktu dan konsentrasi klorofil. Agregasi zooplankton berada pada lapisan permukaan 0-25 meter untuk setiap waktu pengamatan, bersamaan dengan nilai konsentrasi khorofil yang tinggi yakni mencapai $2,1 \mathrm{mg} / \mathrm{m}^{3}$. Nilai volume hamburan balik akustik rerata pada strata kedalaman 0-25 meter adalah -84,31 dB, pada kedalaman 25-50 meter sebesar -82,02 dB dan pada kedalaman 50-75 meter sebesar -83,9 dB.
\end{abstract}

Kata kunci: Volume hamburan, migrasi vertikal, zooplankton

\section{ABSTRACT}

Analysis of the vertical migration of zooplankton in the Banda Sea was carried out based on the acoustic backscattering values obtained from the measurements conducted from November 21 to 30, 2013 using an acoustic instrument called SIMRAD EK 500, which was mounted on the research vessel named Baruna Jaya VII. The analysis result showed that the vertical migration of zooplankton in the Banda Sea was a time function and chlorophyll concentration. Zooplankton aggregation was in the surface layers of 0-25 meters for each time observation, along with the high value chlorophyll concentration reaching $2.1 \mathrm{mg} / \mathrm{m}^{3}$. The mean value of the acoustic backscattering volume in the depth strata of 0-25 meters was $-84.31 \mathrm{~dB}$, at a depth of 25-50meters $-82.02 \mathrm{~dB}$ and at a depth of 50-75 meters $-83.9 \mathrm{~dB}$.

Keywords: Scattering volume, vertical migration, zooplankton

\section{PENDAHULUAN}

Laut Banda memiliki posisi yang sangat strategis dalam menentukan proses perubahan oseanografis di perairan Maluku. Luas Laut Banda sekitar 500 x $1.000 \mathrm{~km}$ dengan kedalaman dapat mencapai 3000 m. Laut ini terpisah dari Samudera Pasifik oleh Laut Halmahera, Laut Seram dan ratusan pulau lainnya. Laut Banda adalah daerah oseanik yang memiliki lapisan permukaan yang luas, sehingga memiliki intensitas cahaya yang cukup namun miskin akan kandungan nutrient.

Konsentrasi nutrient di laut sangat dipengaruhi oleh arus dan berubah terhadap musim, sementara nutrient menentukan kelimpahan zooplankton (Nontjie, 1987). Pengetahuan distribusi populasi zooplankton dalam ruang tiga dimensi dan perubahan strukturnya terhadap waktu merupakan masalah yang penting dalam studi dinamika 
komunitas zooplankton (Chu, Wiebe, \& Copley, 1992). Variasi harian atau setengah harian dari pasang surut terjadi pada semua kolom perairan, tetapi siklus vertikal zooplankton hanya terjadi di atas termoklin. Hal ini disebabkan oleh bermigrasinya zooplankton secara aktif pada lapisan tersebut.

Instrumen akustik, efektif dalam mendeteksi dan mendiskripsikan lapisan tipis zooplankton. Akustik frekuensi tinggi telah digunakan untuk mendapatkan beberapa cara mengumpulkan data distribusi zooplankton secara vertikal maupun horizontal (Greene \& Wiebe, 1998). Keunggulan metode akustik adalah cepat dalam perolehan data, real time dan tidak mengganggu organisme yang menjadi objek yang diukur (MacLennan and Simmonds, 1992). Sehingga metode ini memiliki potensi besar untuk digunakan dalam kajian oseanografi biologi (Linstrom and Nowlin, 1989).

Penelitian migrasi vertikal zooplankton di perairan oseanik penting dilakukan. Dalam makalah ini diuraikan hasil analisis migrasi harian zooplankton di Laut Banda yang dihubungkan dengan parameter oseanografis dan ketersediaan makanan. Pola penyebaran zooplankton dapat dijadikan sebagai salah satu indikator biologi dalam menentukan perubahan kondisi perairan dan komunitas zooplankton. Diharapkan uraian ini dapat memberikan gambaran bagi pemahaman yang lebih baik mengenai fenomena migrasi vertikal zooplankton pada daerah oseanik di Indonesia.

\section{BAHAN DAN METODE}

Pengukuran data akustik di Laut Banda pada tanggal 21-30 November 2013 (Gambar 1) dilakukan di setiap stasiun dengan perekaman data 1 jam. Data akustik diukur menggunakan Simrad EK 500 dengan frekwensi $38 \mathrm{kHz}$, dan diolah dengan software Echoview 4.8. Data oseanografi diperoleh dengan menggunakan instrumen Conductivity Temperature Depth (CTD) Sea-Bird 911. Pengambilan data zooplankton dilakukan pada tiga kedalaman 0,25 dan $75 \mathrm{~m}$ dengan rosette sampler.

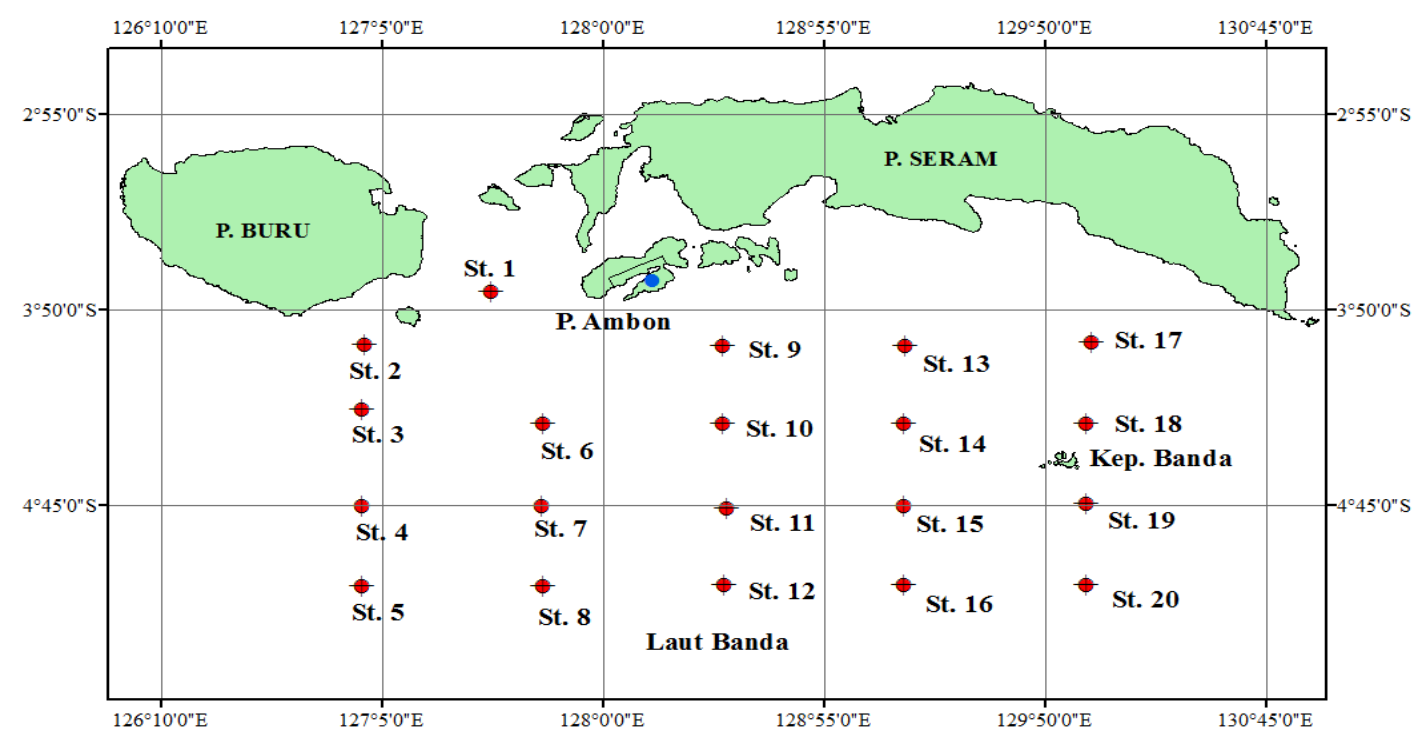

PETA LOKASI PENELITIAN

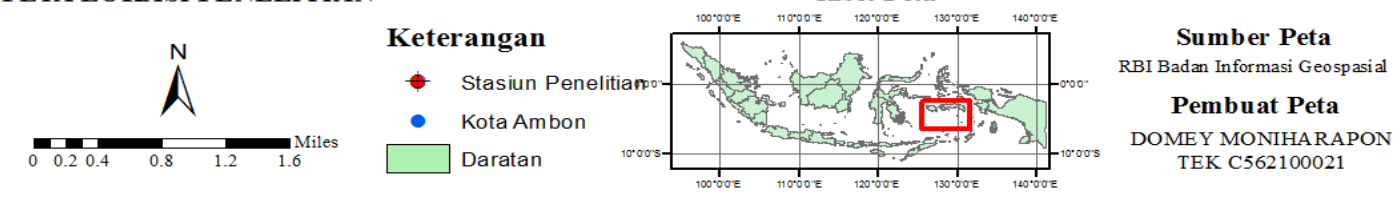

Gambar 1. Sebaran stasiun pengukuran di Laut Banda

Figure 1. Distribution of observation stations in the Banda Sea

Sumber: Badan Informasi Geospasial 
Volume hamburan balik akustik, SV (dB) yang dihasilkan merupakan penjumlahan dari pantulan setiap organisme zooplankton dan dapat dirumuskan sebagai berikut (Stanton, Wiebe, Chu, Benfield, Scanlon, \& Martin, 1994):

$$
\begin{aligned}
\mathrm{Sv} & =\mathrm{N}_{\mathrm{a}} \sigma_{\mathrm{a}}+\mathrm{N}_{\mathrm{b}} \sigma_{\mathrm{b}}+\ldots+\mathrm{N}_{\mathrm{i}} \sigma_{\mathrm{i}} \\
& =\sum_{i=1}^{m} \mathrm{~N}_{\mathrm{i}} \sigma_{\mathrm{i}} \quad \ldots \ldots \ldots \ldots \ldots
\end{aligned}
$$

dimana $: \sigma_{\mathrm{a}, \mathrm{b}} \quad=$ Kekuatan hambur balik dari zooplankton jenis $\mathrm{a}, \mathrm{b}, \ldots, \mathrm{i}$

$\mathrm{N}_{\mathrm{a}, \mathrm{b}} \quad=$ Jumlah zooplankton menurut Jenis $a, b, \ldots, i$

SV adalah logaritmik dari perubahan nilai volume kekuatan hambur balik (Sv) di rumuskan sebagai berikut (Greenlaw, 1979):

$$
\mathrm{SV}=10 \log (\mathrm{Sv})(\mathrm{dB})
$$

Sampel zooplankton diidentifikasi menggunakan sistem standar identifikasi zooplankton, dimana zooplankton diamati menggunakan mikroskop binokuler untuk melihat jenis dan jumlah. Metoda identifikasi zooplankton berdasarkan referensi dari Hutabarat dan Evans (1986). Kelimpahan zooplankton dihitung dengan menggunakan rumus sebagai berikut (Wickstead, 1965):

$\mathrm{D}=\mathrm{n} \times 1 / \mathrm{f} \times 1 / \mathrm{v}\left(\mathrm{ekor} / \mathrm{m}^{3}\right)$

dimana: $\mathrm{n}=$ Jumlah zooplankton (ekor)

$$
\begin{aligned}
& \mathrm{f}=\text { Fraksi yang diambil }(\mathrm{ml}) \\
& \mathrm{v}=\text { Volume air tersaring }(1)
\end{aligned}
$$

\section{HASIL DAN PEMBAHASAN}

\subsection{Akustik Zooplankton}

Pengolahan data akustik menghasilkan nilai volume hamburan balik rata - rata menurut waktu dan kedalaman.

Pada Gambar 2 memperlihatkan sebaran zooplankton ada pada lapisan permukaan 0-25 meter pada setiap jam pengamatan. Sedang di kedalaman 25-50 meter hanya ada pada jam 09.00 dan 00.00. Pada Jam 00.00 sebaran zooplankton ada pada tiga lapisan kedalaman 0,25 dan 50 meter. Nilai SV bervariasi pada setiap jam dan kedalaman pengamatan. Pada lapisan 0-25 meter nilai SV terbesar sebesar $-83,24 \mathrm{~dB}$ dan terendah sebesar $-85,75 \mathrm{~dB}$.

Nilai SV menyatakan kepadatan zooplankton (Stanton et al., 1994). Jam 00.00 zoplankton memadati ketiga lapisan kedalaman dengan nilai volume hambur balik masing-masing -84,25; $-81,88$ dan $-83,9$ dB. Migrasi vertikal zooplankton kadang-kadang dapat mencapai tiga lapisan kedalaman (Sutomo et al., 1994).

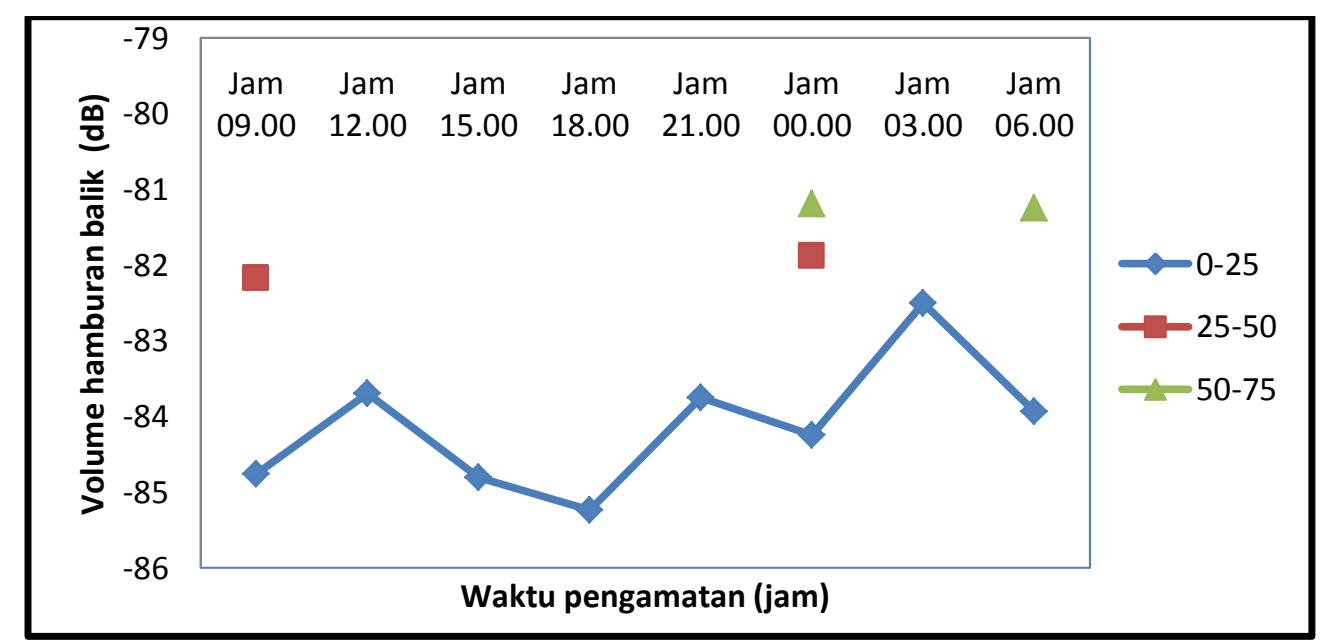

Gambar 2. Nilai SV menurut waktu dan kedalaman

Figure 2. SV value according to the time and depth Sumber: Hasil pengolahan data 
Tabel 1. Deskripsi statistik agregasi zooplankton menurut waktu

Table 1. Statistical description of the aggregation of zooplankton by time

\begin{tabular}{cccccccc}
\hline Waktu & N & Jarak & Minimum & Maksimum & Rataan & Std. Deviasi & Varians \\
\hline $00.00-06.00$ & 120 & 10,83 & $-90,84$ & $-80,01$ & $-82,3015$ & 2,16702 & 4,696 \\
$06.00-12.00$ & 120 & 16,99 & $-97,01$ & $-80,02$ & $-83,2737$ & 3,54643 & 12,577 \\
$12.00-18.00$ & 60 & 15,42 & $-96,75$ & $-81,33$ & $-86,4243$ & 4,21645 & 17,778 \\
$18.00-00.00$ & 65 & 15,98 & $-95,98$ & $-80,00$ & $-83,6877$ & 3,52327 & 12,413 \\
\hline \multicolumn{7}{l}{ Sumber: Hasil pengolahan data }
\end{tabular}

Sumber: Hasil pengolahan data

Pada Tabel 1 terlihat agregasi zooplankton pada waktu malam sampai dengan menjelang tengah hari berada dalam kelompok yang relatif padat $(\mathrm{N}=120)$, jumlah ini akan menghilang di waktu siang $(\mathrm{N}=60)$. Pada waktu sore menjelang malam terlihat pergerakan dari zooplankton dan membentuk agregasi yang lebih banyak $(\mathrm{N}=65)$. Secara spesifik agregasi ini dalam jumlah yang cukup padat sehingga pada jam 00.00 nilai scattering volum dapat mencapai $-80,01 \mathrm{~dB}$. Rataan nilai volume hambur balik malam hari
$-82,30 \mathrm{~dB}$ dan siang hari $-86,42 \mathrm{~dB}$ (Selisih rerata nilai volume hambur balik antara dapat mencapai $-4 \mathrm{~dB}$ ), artinya terjadi migrasi vertikal pada perairan ini.

Keragaman tertinggi terdapat pada jam 12.0018.00 (Gambar 3). Hal ini menandakan nilai volume hambur balik dalam rentang yang panjang dan agregasi dalam kelompok yang cukup beragam.

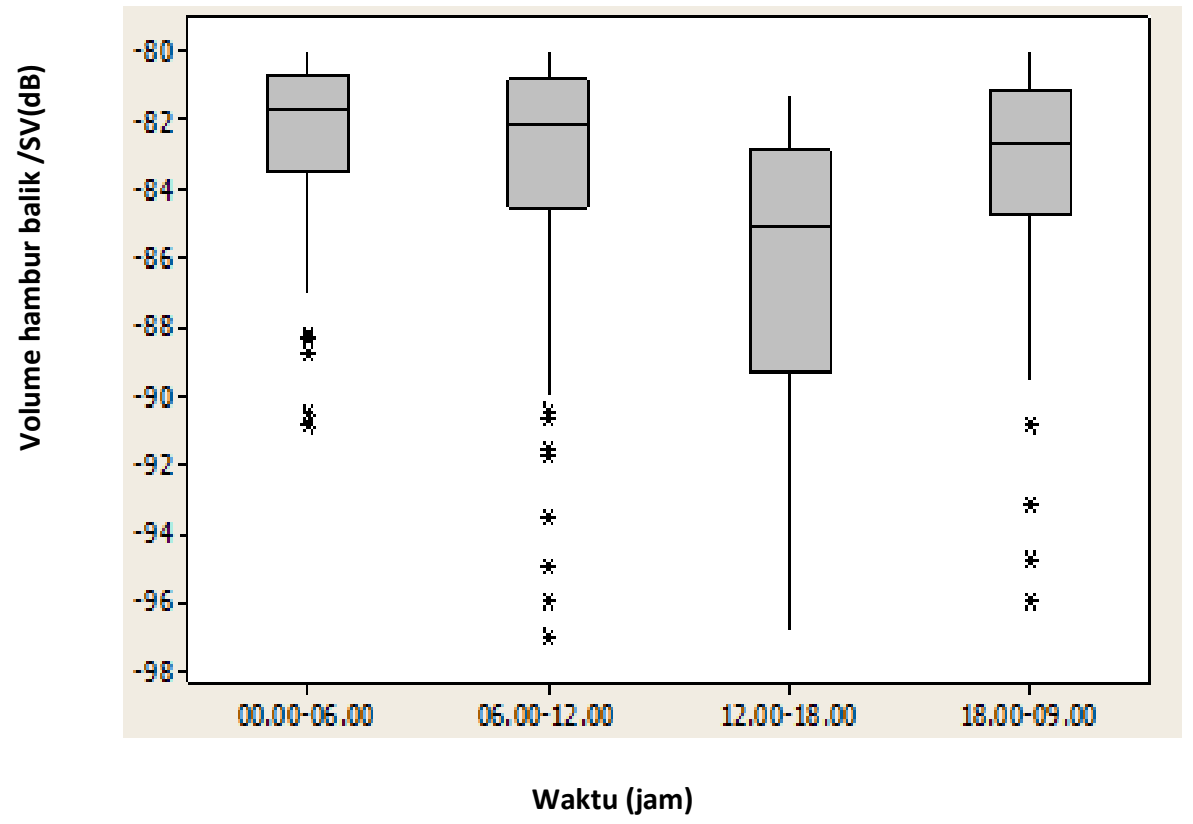

Gambar 3. Sebaran nilai SV terhadap waktu

Figure 3. SV value distribution vs time

Sumber: Hasil pengolahan data 


\subsection{Taxa biologi zooplankton dan faktor oseanografi}

Hasil analisis biologi zooplankton dapat dilihat pada Gambar 4, terlihat zooplankton pada jam: 12.00-15.00 dalam jumlah yang banyak, sedangkan untuk waktu pengamatan jam: 00.0003.00, zooplankton hampir berada di tiga strata kedalaman $(0-25,25-50$ dan 50-75 m) pada jam tersebut terdapat jumlah individu yang sangat banyak, kelimpahannya dapat mencapai 26500 ekor $/ \mathrm{m}^{3}$. Calanoida adalah kelompok yang mendominasi komposisi pada setiap jam

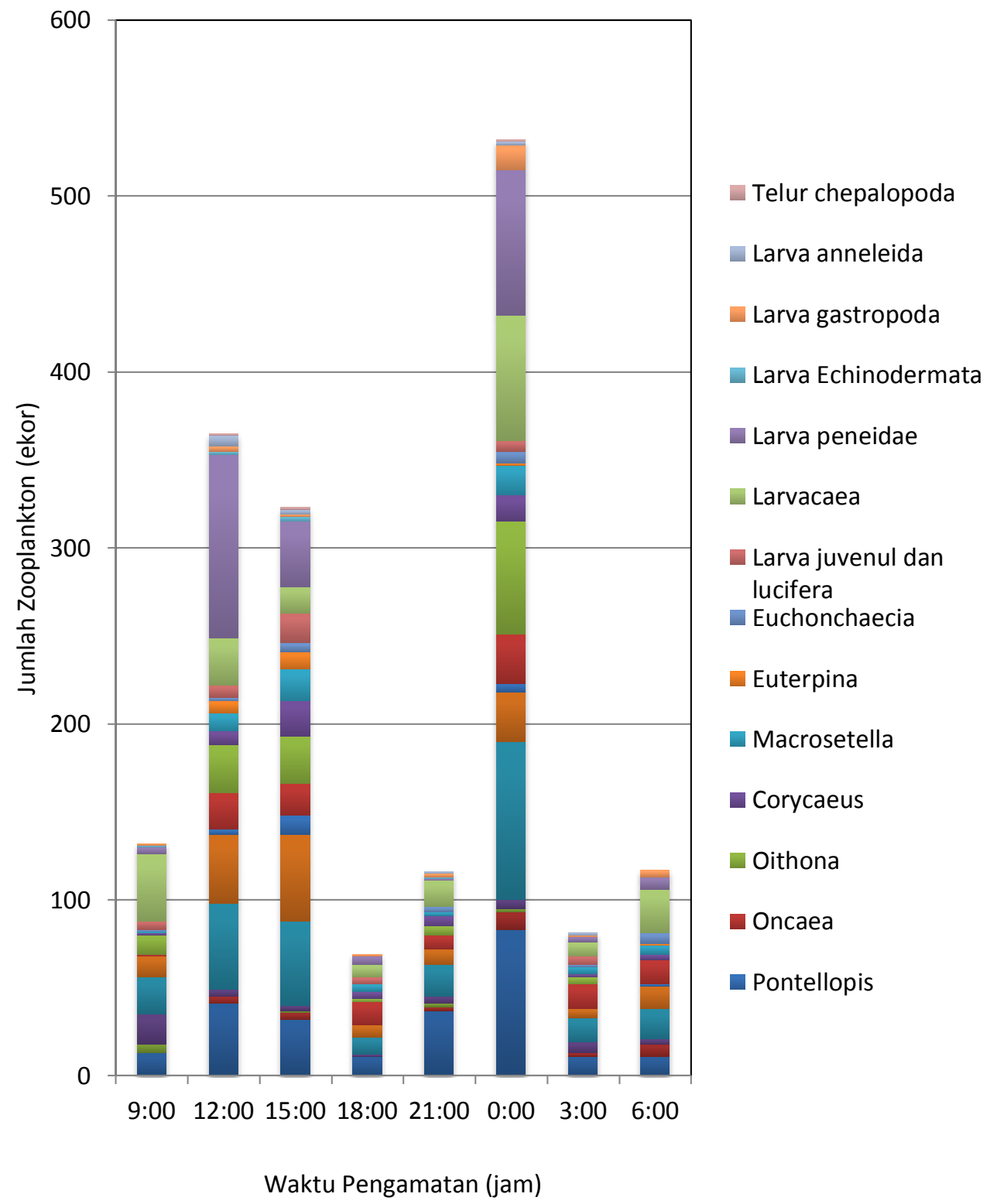

Gambar 4. Jumlah individu zooplankton berdasarkan waktu pengamatan tanggal 21-30 November 2013

Figure 4. Number of individual zooplankton according to observation time when November 21 to 30, 2013 Sumber: Hasil pengolahan data 
Kelas copepod dan filum crustacea yang mendominasi 50-80 \% secara ekologis dari plankton yang berada di lautan (Nybakken, 1982). Kelompok calanoida berada dalam golongan ini, pada Gambar 5. memperlihatkan presentase kelimpahan golongan ini mencapai $45 \%$. Famili zooplankton pada lokasi pengukuran di Laut Banda ditemukan 7 (tujuh) jenis yaitu: famili Calanoida dengan kelimpahan (45\%), Cyclopoida $(18 \%)$, Meroplankton (17 \%), Urochordata (11 $\%)$, Harpactioda (5 \%), Sergestidae (3\%) dan Ostracoda (1\%).
Gambar 6 menunjukan kelimpahan zooplankton menurut waktu dan kedalaman. Kelimpahan zooplankton di tiga strata kedalaman pengukuran pada jam: 00.00-00.03 relatif padat dapat mencapai $1575 \mathrm{ekor} / \mathrm{m}^{3}$. Pada saat pengukuran dilakukan pada kedalaman ini nilai klorofil maximum ditemukan pada keseluruhan stasiun pengamatan, karena keberadaan zooplankton sangat dipengaruhi ketersediaan fitoplankton. Kelimpahan zooplankton sangat ditentukan oleh adanya fitoplankton (Davis,1995) dan Arinardi,1997).
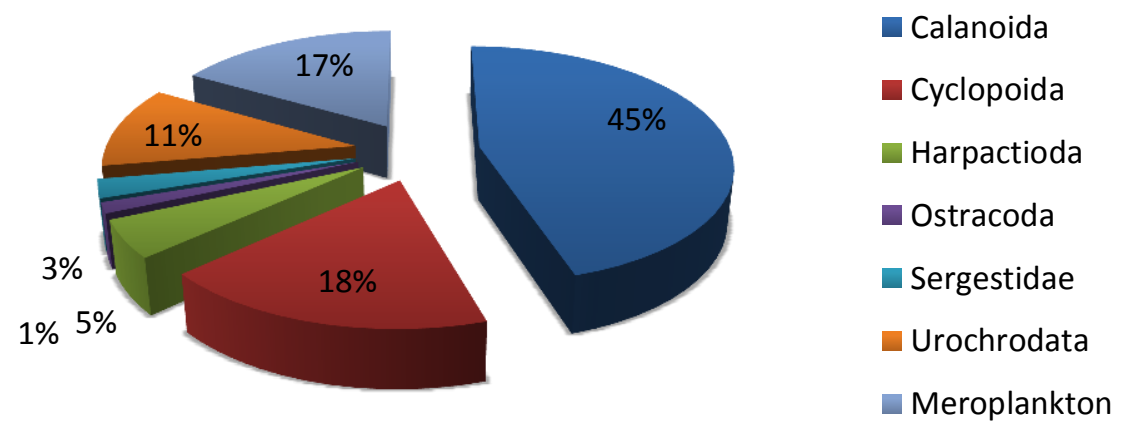

Gambar 5. Presentase kelimpahan menurut kelompok zooplankton

Figure 5 . Percentage of zooplankton abundance by group

Sumber: Hasil pengolahan data

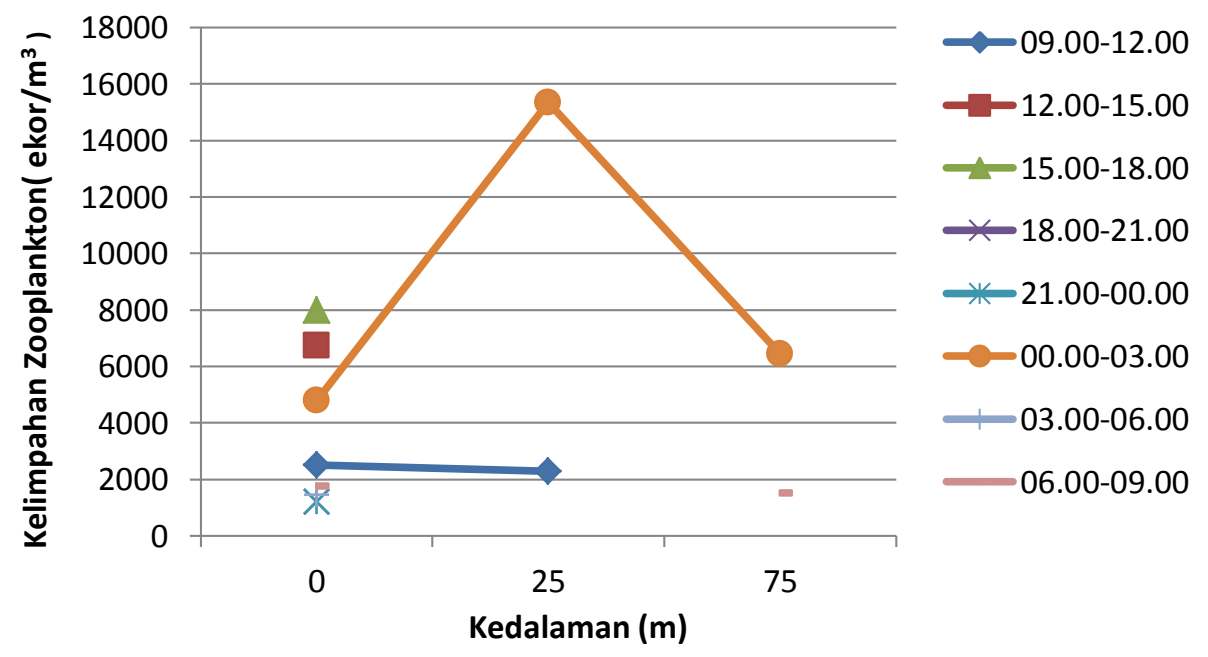

Gambar 6. Kelimpahan zooplankton menurut waktu dan kedalaman

Figure 6. Zooplankton abundance in time and depth

Sumber: Hasil pengolahan data 
Melimpahnya zooplankton sebagai akibat melimpahnya fitoplankton diduga disebabkan kondisi oseanografis seperti arus, salinitas, temperatur, dan visibilitas perairan di stasiun pengamatan sangat cocok untuk berkembangnya kedua jenis plankton tersebut.

Pola pergerakan dari kelompok copepod ini mendekati permukaan air pada waktu sore sampai menjelang tengah malam untuk memperoleh makanan berupa fitoplankton yang keberadaannya ditentukan oleh faktor oseanografi (Ohman, 1990; Ruttner, 1975).
Pada Gambar 7, terlihat bahwa sebaran konsentrasi klorofil-a yang tinggi $\left(0,5-2,1 \mathrm{mg} / \mathrm{m}^{3}\right)$ berada pada kedalaman antara 10-80 meter sepanjang waktu pengukuran (jam: 00.00 s/d 09.00).

Konsentrasi ini sangat memberi pengaruh bagi keberadaan zooplankton. Perairan dengan konsentrasi klorofil-a yang tinggi mengisyaratkan perairan itu subur. Pada saat survey dilakukan konsentrasi klorofil dapat mencapai nilai 2,1 $\mathrm{mg} / \mathrm{m}^{3}$.

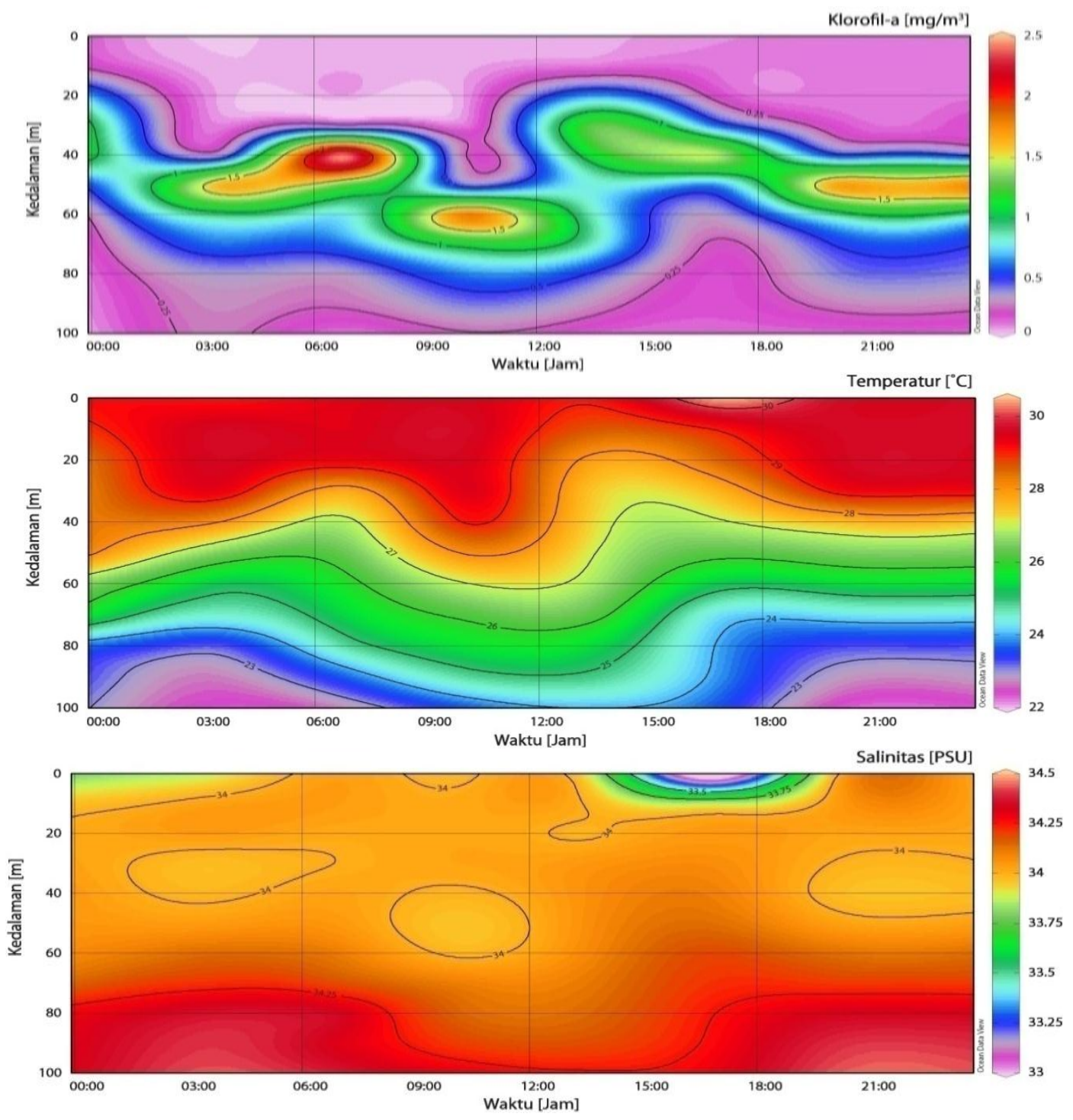

Gambar 7. Sebaran menegak klorofil (atas), suhu (tengah) dan salinitas (bawah) di Laut Banda berdasarkan pengukuran tanggal 21-30 November 2013

Figure 7. Uprise chlorophyll distribution (top), temperature (middle) and salinity (bottom) in the Banda sea when November 21 to 30,2013

Sumber: Hasil pengolahan data 
Konsentrasi klorofil-a sangat mempengaruhi migrasi vertikal dari zooplankton. Regresi linier membuktikan hubungan antara kelimpahan dan klorofil-a memiliki hubungan yang sangat kuat sebesar $r=0.934$. Temperatur permukaan hingga kedalaman $100 \mathrm{~m}$ di Laut Banda berkisar antara 22,19 ${ }^{\circ} \mathrm{C}$ (nilai minimum) dan $29,13{ }^{\circ} \mathrm{C}$ (nilai maksimum). Sedangkan kisaran nilai salinitasnya adalah 33,83 PSU di permukaan dan 34,32 PSU pada kedalaman 100 meter. Di perairan tropis seperti Indonesia variasi suhu air laut sepanjang tahun tidak besar, suhu permukaan laut berkisar antara $27{ }^{\circ} \mathrm{C}$ sampai $35{ }^{\circ} \mathrm{C}$, dimana suhu tersebut merupakan suhu yang ideal untuk kehidupan di laut.

Menurut Steinberg et al. (2002), migrasi vertikal zooplankton sangat bergantung kepada respons dan adaptasi organisme ini terhadap perubahan lingkungan misalnya temperatur, salinitas, makanan, oksigen dan predator. Peran salinitas sangat penting dalam kehidupan organisme, misalnya distribusi biota akuatik sangat erat kaitannya dengan salinitas, organisme yang hidup cenderung mempunyai toleransi terhadap perubahan salinitas sampai dengan 15 PSU (Nybaken, 1982). Dalam hubungannya dengan rantai makanan, terbukti zooplankton merupakan sumber pangan bagi semua ikan pelagis. Kelimpahan zooplankton sering dikaitkan dengan kesuburan perairan (Arinardi,1997).

Laut Banda adalah perairan oseanik, dimana salinitas tidak tergantung pada run-off daratan atau sungai-sungai tetapi perubahan salinitas hampir disebabkan oleh penguapan dan presipitasi. Hasil penelitian menunjukan pada waktu siang menjelang sore nilai salinitas berkisar antara 33 PSU sampai 33,75 PSU dan malam sampai pagi berkisar pada 34 PSU sampai 34,20 PSU, sehubungan dengan penguapan akibat penetrasi sinar matahari.

\section{KESIMPULAN DAN SARAN}

Migrasi vertikal zooplankton di Laut Banda yang ditunjukan dengan pergerakan dan agregasi zooplankton dari lapisan yang lebih dalam ke permukaan perairan. Migrasi vertikal zooplankton di Laut Banda terjadi pada waktu malam hari dengan dominan zooplankton kelompok copepod. Kejadian migrasi vertikal ini ditunjukkan dengan
SV pada siang dan malam hari yang berbeda dalam rentang cukup lebar, yaitu antara $-4,69 \mathrm{~dB}$ dan $17,77 \mathrm{~dB}$.

Agregasi zooplankton yang padat bersamaan dengan nilai konsentrasi klorofil yang tinggi yang dapat mencapai $2,1 \mathrm{mg} / \mathrm{m}^{3}$ yang hampir selalu berada pada lapisan permukaan (0-25 meter) untuk setiap waktu pengamatan.

\section{UCAPAN TERIMA KASIH}

Penulis mengucapkan terima kasih kepada Kepala Pusat Penelitian Laut Dalam LIPI atas bantuan peralatan dan fasilitas Kapal Baruna Jaya VII. Ucapkan terima kasih penulis disampaikan pula kepada teman-teman pekerja di Lapangan, yaitu: Asep Ma,mun, S.Pi, Ir. Jakobus Latumeten, M.Si, Ir. J Lekalette, Ibu Omi Hehakaja. Atas bantuan dan kerjasamanya selama pengukuran dan pengolahan data.

\section{DAFTAR PUSTAKA}

Arinardi, O. H. (1997). Status pengetahuan plankton di Indonesia. Oseanologi dan Limnologi di Indonesia. Puslitbang - LIPI. Jakarta.

Bayli, I. A. H. (1986). Aspects of diel vertical migration in zooplankton and its enigma variations. Limnologi in Australia. CSIRO Aust, Melbourne, Australia, 349-368.

Chu, D., Wiebe, P., \& Copley, N. (1992). Interference of material properties of zooplankton from acoustic and resistivity measurement. ICES Journal of Marine Science, 57, 1128-1142.

Greenlaw, C. F. (1979). Acoustical estimation of zooplankton population. Limnologi and Oceanografi, 24, 226-242.

Greene, C. H. \& Wiebe, P. H. (1998). New devolepments in bioacoustical oceanography. Sea Technol, 229, 27-29.

Hutabarat, S., \& Evans, S. M. (1986). Kunci Identifikasi Zooplankton. UI Press. 98 hal.

Mac Lennan, D. N., \& Simmonds, E. J. (1992). Fisheries Acoustic. Chapman and Hall. 325 p.

Nontjie, A. (1987). Laut Nusantara. Penerbit Djambatan. Jakarta.

Nybakken, J. W. (1992). Biologi laut: Suatu Pendekatan Ekologis. Alih bahasa Eidman dkk. P.T Gramedia Pustaka Utama. Jakarta.

Ohman, M. D. (1990). The demographic benefis of diel vertical migration by zooplankton Ekological Monograph, 60: 257-281. 
Ruttner, F. (1975). Fundamental of Limnology. University of Toronto Press. Toronto of euphasiids using $120 \mathrm{kHz}$ sounder and their In situ orientation. Canadian Journal of Fisheries and Aquatic Sciences, 37, 693-702.

Stanton, T. K., Wiebe, P., Chu, D., Benfield, M. C., Scanlon, L. \& Martin, L. (1994). On acoustic estimation of zooplankton biomass. J. Mar. Sci, 51, 502-512.

Steinberg, D. K., Goldthwait, S. A., \& Hansel, D. A. (2002). Zooplankton vertical migration and the active transport of dissolved organic and in organic nitrogen in the Sargasso Sea. Deep Sea Research I, 49, 1445-1461.

Sutomo, A. B., \& Nugroho, D. (1994). Penggunaan fish finder dan jarring nansen untuk studi migrasi vertical zooplankton. Makalah dibacakan pada Symposium Perikanan Indonesia, 1993.

Wickstead, J. D. (1965). An Introduction to the Study of Plankton. Vol 1, 1-60. London. Hutchinson Tropical Monograph. 
